$\begin{array}{ll}\text { Received } & : \text { 10 Agustus 2020 } \\ \text { Revised } & : \text { 13 Desember 2020 } \\ \text { Accepted } & : \text { 14 Desember 2020 } \\ \text { Online } & : \text { 15 Desember 2020 } \\ \text { Published } & : \text { 18 Desember 2020 }\end{array}$

\title{
Kwetiau Kacang Hijau Teri Yang Potensial Sebagai Pemenuh Kebutuhan Nutrisi Pada Anak-Anak
}

\author{
Muhammad Agung Aprialdi ${ }^{1, a)}$, Fitri Andriyani ${ }^{2}$, Nico Andreas ${ }^{3}$ \\ ${ }^{1}$ Tata Boga, Fakultas Teknik, Universitas Negeri Jakarta \\ ${ }^{2}$ Pendidikan Biologi, Fakultas Matematika dan Ilmu Pengetahuan alam, Universitas Negeri \\ Jakarta \\ ${ }^{3}$ Kimia, Fakultas Matematika dan Ilmu Pengetahuan alam, Universitas Negeri Jakarta \\ 凶: ${ }^{a}$ muhammadagungaprialdi_1508518014@mhs.unj.ac.id
}

\begin{abstract}
Kwetiau are quite popular food in Indonesia, but Kwetiau will not be one of the micronutrients, namely calcium, even though the daily nutritional needs especially in children must be met so that the child's status is good. Inadequate nutritional needs in children can cause malnutrition and interfere with children's growth and development in 1000 days of growth. However, easy access to inexpensive nutritious food is a particular obstacle for parents in Indonesia, especially those living on the poverty line. The aim of this research is to make rice noodles made from mung beans (Vigna radiata) combined with anchovies (Stelephorus sp.) As a nutrient fulfillment in children. The research method used in this study is an experiment with direct trials. The data analysis technique was carried out in a descriptive qualitative way to describe the object of research based on the facts that appear. Kwetiau with the addition of mung bean flour and anchovies have the benefit of being healthy foods that are rich in good nutrition to meet the nutritional needs of children. This can be seen from the content of green beans and anchovies which have various vitamins, proteins, calcium and minerals that are good for the body. The final result obtained is a smooth and chewy textured product and not easily damaged when cooked and has the potential to increase the nutritional needs of children so it does not require a long time in the process of chewing for consumption by children.
\end{abstract}

Keywords: Anchovy, Mung Bean, Kwetiau, Malnutrition.

\begin{abstract}
Abstrak
Kwetiau merupakan makanan yang populer di Indonesia, namun kwetiau kurang akan salah satu zat gizi mikro yaitu kalsium. Kebutuhan nutrisi yang tidak sesuai pada anak-anak dapat menyebabkan malnutrisi dan mengganggu tumbuh kembang anak di 1000 hari masa pertumbuhan. Namun akses kemudahan mendapatkan makanan bernutrisi yang murah menjadi kendala tersendiri bagi orang tua di Indonesia terutama yang hidup di garis kemiskinan. Penelitian ini bertujuan untuk membuat produk kwetiau berbahan dasar kacang hijau (Vigna radiata) yang dikombinasikan dengan ikan teri (Stelephorus sp.) sebagai pemenuhan nutrisi pada anak-anak. Metode penelitian yang dilakukan pada penelitian ini yaitu eksperimen dengan uji coba secara langsung. Teknik analisis data dilakukan secara
\end{abstract}


deskriptif kualitatif untuk mendiskripsikan objek penelitian berdasarkan fakta-fakta yang tampak. Kwetiau dengan penambahan tepung kacang hijau dan ikan teri memiliki manfaat sebagai makanan sehat yang kaya akan nutrisi yang baik untuk memenuhi kebutuhan nutrisi pada anak-anak. Hal ini dapat dilihat dari kandungan kacang hijau dan ikan teri yang memiliki berbagai vitamin, protein, kalsium serta mineral yang baik bagi tubuh. Hasil akhir yang didapatkan adalah produk bertekstur halus dan kenyal serta tidak mudah rusak ketika dimasak dan berpotensi untuk menambah kebutuhan nutrisi pada anak-anak sehingga tidak memerlukan waktu yang lama dalam proses mengunyah untuk dikonsumsi oleh anak-anak.

Kata-kata kunci: Ikan teri, Kacang Hijau, Kwetiau, Malnutrisi.

\section{PENDAHULUAN}

Indonesia adalah negara dengan sumber daya alam yang melimpah, serta memiliki keanekaragaman komoditi yang berbeda setiap daerahnya. Hal tersebut disebabkan karena perbedaan letak geografis yang berbeda setiap daerah. Perbedaan sumber daya alam membuat Indonesia memiliki pangan yang beragam dan melimpah. Namun walaupun Indonesia disebut sebagai negara dengan sumber daya alam yang melimpah tetapi masih memiliki masalah mengenai kekurangan pangan dan bermasalah dengan gizi buruk. Berdasarkan Profil Kemiskinan Indonesia oleh BPS, pada Maret 2019 jumlah penduduk miskin mencapai 25.14 juta orang (BPS, 2019) dimana status kemiskinan akan berbanding lurus dengan status gizi penduduknya. Hal ini terbukti dengan tingginya angka stunting balita yang mencapai $30.79 \%$ pada Tahun 2018 .

Faktor penyebab stunting adalah kemiskinan, sosial budaya, peningkatan paparan terhadap penyakit infeksi, kerawanan pangan dan akses masyarakat terhadap pelayanan kesehatan. Oleh karena itu pemerintah Indonesia melalui Kementrian Kesehatan memfokuskan peningkatan gizi masyarakat yang tercantum dalam Renstra Kemenkes 20202024. Hal ini sesuai dengan SDGs nomor 2 tentang Zero Hunger yaitu pada tahun 2030 mencapai target-target yang sudah disepakati secara internasional tentang gizi buruk dan penelantaran pada anak balita, dan mengatasi kebutuhan nutrisi untuk para remaja putri, ibu hamil dan menyusui dan manula.

Kebutuhan nutrisi yang tidak sesuai pada anak-anak dapat menyebabkan malnutrisi dan dapat mengganggu tumbuh kembang anak di masa 1000 hari masa pertunbuhannnya. Menurut World Health Organization anak penderita gizi buruk berisiko kematian 5 sampai 20 kali lebih besar daripada anak dengan nutrisi baik.

Sebuah riset menunjukan bahwa terdapat faktor-faktor yang berpengaruh terhadap malnutrisi pada balita, diantaranya adalah tingkat pendidikan ibu, berat anak ketika lahir, jarak kelahiran dan riwayat infeksi kronis (Departemen Ilmu Kesehatan Masyarakat Fakultas Kedokteran Universitas Islam Indonesia Yogyakarta pada tahun, 2013).

Kecukupan gizi harian pada anak harus dapat terpenuhi terlebih peran ibu dalam pemilihan produk makanan menjadi hal yang paling utama. Namun akses kemudahan mendapatkan makanan bergizi yang murah menjadi kendala tersendiri bagi ibu-ibu di Indonesia terutama yang hidup di garis kemiskinan. Oleh karena itu perlu adanya produk makanan yang mudah didapat dan murah serta bernilai gizi tinggi, salah satunya adalah produk mie.

Produk mie merupakan salah satu makanan yang sangat disukai oleh masyarakat Indonesia. Berdasarkan World Instant Noodles Association, Indonesia merupakan negara ke2 dengan jumlah pengonsumsi mie instan terbanyak di dunia yaitu mencapai 12.6 Miliar per 
Tahun (Kusnandar, 2019). Konsumsi mie yang tinggi ini menunjukkan bahwa pengembangan produk berbasis mie sebagai makanan bergizi bagi anak-anak berpotensi untuk dilakukan. Namun di sisi lain, konsumsi mie instan yang tinggi berakibat pada tingginya angka import biji gandum dan meslin. Produk serelian gandum dan meslin merupakan salah satu bahan utama dalam pembuatan mie. Berdasarkan data dari BPS jumlah import biji gandum dan meslin pada tahun 2017 mencapai 11,434,134 kg dimana meningkat hampir tiga kali lipat pada kurun waktu 7 tahun terakhir (BPS, 2019).

Padahal menurut Aswatan (2000), terdapat empat jenis mie yang tersebar seacara umum yaitu mie segar, mie kering, mie instan, dan mie basah. Berdasarkan bahan bakunya, mie dapat terbuat dari beberapa tepung diantaranya bihun yang terbuat dari tepung beras, soun terbuat dari tepung kacang hijau, serta kwetiau yang terbuat dari tepung tapioka dan tepung beras. Beberapa jenis mie ini berpotensi dikembangkan karena bahan baku yang digunakan merupakan bahan baku lokal sehingga diharapkan mampu menekan angka import gandum dan meslin. Tingginya tingkat konsumsi mie dan besarnya potensi pengembangan produk berbasis mie berbahan lokal. Inovasi produk makanan sehat berbasis mie untuk membantu kebutuhan nutrisi pada anak-anak. Salah satu produk berbasis mie yang dapat dikembangkan adalah kwetiau. Kwetiau dipilih karena mie ini merupakan salah satu makanan yang cukup banyak dikonsumsi oleh masyarakat disamping dari jenis mie-mie lainnya.

Kwetiau adalah salah satu variasi dari produk mie yang berbasis tepung beras berwarna putih, dengan tekstur yang kenyal. Kwetiau merupakan makanan yang cukup populer di Indonesia, namun kwetiau kurang akan salah satu zat gizi mikro yaitu kalsium, padahal kebutuhan gizi harian terutama pada anak-anak harus terpenuhi agar status anak baik. Untuk itu perlu adanya penambahan makronutrien dan mikronutrien pada kwetiau diantaranya dengan penambahan protein (makronutrien) danf kalsium (mikronutrien). Pembuatan kwetiau kacang hijau teri sebagai kwetiau dengan mengganti tepung tapioka menjadi tepung kacang hijau dilakukan untuk menambah kandungan nutrisi baik yaitu protein dan kalsium pada kwetiau. Kacang hijau dipilih sebagai bahan pengganti tepung tapioka karena kacang hijau masuk kedalam kelompok serelia tinggi protein terbaik kedua setelah kacang kedelai yang mengandung berbagai vitamin seperti A, B1, C, dan E, serta mengandung beberapa zat lain yang sangat bermanfaat bagi tubuh manusia, diantaranya amilum, besi, belerang, kalsium, minyak lemak, mangan, magnesium dan niasin. Kacang hijau juga memiliki manfaat dalam melancarkan buang air besar (Purwono dan Hartono, 2005).

Kacang hijau berpotensi sebagai pengganti bahan baku pembuatan kwetiau terutama pada penggantian tepung tapioka. Berdasarkna data ekspor dan impor diketahui tepung yang terbuat dari singkong masih diimpor oleh Indonesia sebesar 500.000 ton pada tahun 2018 . Disisi lain produksi kacang hijau di Indonesia sangat besar sehingga Indonesia mengekspor sebesar 11.652 ton kacang hijau pada bulan Januari hingga Agustus 2018 ketika Negara Cina, Filipina, dan Taiwan.

Pemanfaatan kacang hijau dalam pembuatan Kwetiau sejalan dengan program diverifikasi pangan lokal melalui Kementarian Pertanian yang juga seusai dengan SDG's nomor 2 tentang Zero Hunger yaitu mengenai ketahanan pangan. Selain penambahan kacang hijau, dilakukan juga penambahan ikan teri. Tulang ikan teri banyak mengandung protein dan kalsium. Tiap 100 gram teri segar mengandung energi $77 \mathrm{kkal}$; protein 16 gr; lemak $1.0 \mathrm{gr}$; kalsium $500 \mathrm{mg}$; phosfor $500 \mathrm{mg}$; besi $1.0 \mathrm{mg}$; Vit A 47; dan Vit B $0.1 \mathrm{mg}$ (Gunawan, 2008). Kandungan kalsium yang terdapat pada ikan teri tinggi dan sangat baik untuk menjaga tulang tetap sehat dan kuat. Tidak hanya kalsium, ikan teri juga memiliki kandungan vitamin K, magnesium, serta fosfor yang sama baiknya untuk menjaga kesehatan tulang. Makan teri selama menyusui bahkan dapat mencegah wanita terkena osteoporosis dini (Prasetya, 2020). Sehingga diharapkan penambahan kacang hijau dan teri akan 
meningkatkan protein dan kalsium pada kwetiau sehingga menjadi produk mie yang kaya nutrisi bagi anak-anak.

Berdasarkan latar belakang tersebut penulis melakukan inovasi untuk membuat Kwetiau Kacang Hijau Teri sebagai kwetiau berbahan tepung kacang hijau dan ikan teri yang kaya nutrisi bagi ibu anak-anak diharapkan produk ini dapat bermanfaat bagi masyarakat.

\section{METODE}

Penelitian ini dilaksanakan pada awal bulan Februari sampai akhir Mei 2020 di Laboratorium Tata Boga Universitas Negeri Jakarta. Lokasi penelitian ini memiliki sasaran anak-anak di Posyandu Anyelir 4 Desa Nagrak Selatan dan jajaran RW 04 Kampung Nagrak, Desa Nagrak Selatan, Kecamatan Nagrak. Metode Penelitian yang digunakan adalah Eksperimen dengan tahapan sebagai berikut: 1) mengetahui akar permasalahan malnutrisi di Indonesia; 2) melakukan penelitian terhadap kandungan kacang hijau dan ikan teri; 3) melakukan inovasi produk terhadap kacang hijau dan ikan teri yang di inovasikan sebagai kwetiau dengan mengganti tepung tapioka dengan tepung kacang hijau dan ikan teri yang kaya nutrisi bagi anak-anak.

Perlatan dan bahan yang digunakan dalam penelitian ini meliputi bahan utama berupa tepung kacang hijau, ikan teri, tepung beras, tepung terigu, minyak sayur serta garam. Langkah pembuatan dari kwetiau kacag hijau ikan teri ini yakni : 1). Haluskan kacang hijau dengan blender sampai halus merata, kemudian saring; 2). Campur 50 gr tepung kacang hijau, 10 gr tepung terigu, 35 gr tepung beras, 1 sendok makan minyak sayur, 1 gr garam, dan $150 \mathrm{ml}$ air; 3). Tuang adonan yang telah tercampur kedalam wadah kukusan; 4). Kukus selama 3 menit sampai adonan tidak lengket; 5). Taruh adonan pada loyang kukusan di atas air dingin; 6). Apabila sudah dingin, lapisan adonan dengan minyak sayur lalu potong menggunakan Pasta Rolling.

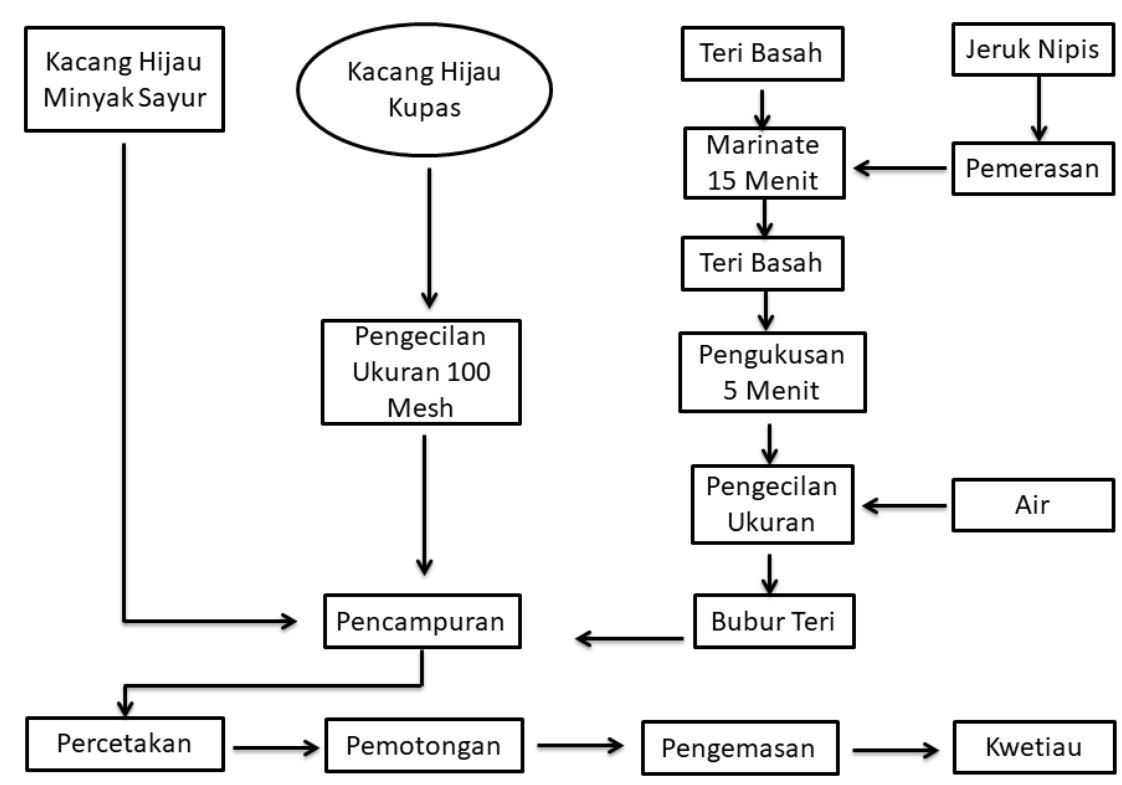

Gambar 1. Diagram Alur Langkah Pembuatan Kwetiau Kacang Hijau Teri 


\section{HASIL DAN PEMBAHASAN}

\section{Hasil}

Kwetiau kacang hijau teri merupakan kwetiau berbahan substitusi tepung kacang hijau dan ikan teri yang kaya nutrisi dalam menunjang ketahanan pangan yang di kemas menggunakan plastik khusus kedap udara sehingga dapat menahan kontaminasi bakteri perusak dari luar. 
Tabel 1. Masa Simpan Kwetiau Kacang Hiau Teri

\begin{tabular}{|c|c|c|c|c|c|c|}
\hline \multirow[b]{2}{*}{ HARI } & \multicolumn{2}{|c|}{ RUANGAN } & \multicolumn{2}{|c|}{ KULKAS } & \multicolumn{2}{|c|}{ FREZZER } \\
\hline & Biasa & Vacum & Biasa & Vacum & Biasa & Vacum \\
\hline Senin & $\begin{array}{l}\text { - Belum ada } \\
\text { perubahan } \\
\text { terhadap } \\
\text { kualitas produk }\end{array}$ & $\begin{array}{l}\text { - Belum ada } \\
\text { perubahan } \\
\text { terhadap } \\
\text { kualitas produk }\end{array}$ & $\begin{array}{l}\text { - Belum ada } \\
\text { perubahan } \\
\text { terhadap } \\
\text { kualitas produk }\end{array}$ & $\begin{array}{l}\text { - Belum ada } \\
\text { perubahan } \\
\text { terhadap } \\
\text { kualitas produk }\end{array}$ & $\begin{array}{l}\text { - Belum ada } \\
\text { perubahan } \\
\text { terhadap } \\
\text { kualitas produk }\end{array}$ & $\begin{array}{l}\text { - Belum ada } \\
\text { perubahan } \\
\text { terhadap } \\
\text { kualitas produk }\end{array}$ \\
\hline Selasa & $\begin{array}{l}\text { - Tidak ada } \\
\text { perubahan } \\
\text { terhadap } \\
\text { kualitas produk }\end{array}$ & $\begin{array}{l}\text { - Tidak ada } \\
\text { perubahan } \\
\text { terhadap } \\
\text { kualitas produk }\end{array}$ & $\begin{array}{l}\text { - Tidak ada } \\
\text { perubahan } \\
\text { terhadap } \\
\text { kualitas produk }\end{array}$ & $\begin{array}{l}\text { - Tidak ada } \\
\text { perubahan } \\
\text { terhadap } \\
\text { kualitas produk }\end{array}$ & $\begin{array}{l}\text { - Tidak ada } \\
\text { perubahan } \\
\text { terhadap } \\
\text { kualitas produk }\end{array}$ & $\begin{array}{l}\text { - Tidak ada } \\
\text { perubahan } \\
\text { terhadap } \\
\text { kualitas produk }\end{array}$ \\
\hline Rabu & $\begin{array}{l}\text { - Tekstur dari } \\
\text { produk mulai } \\
\text { mengalami } \\
\text { perubahan } \\
\text { - Terdapat } \\
\text { udara di dalam } \\
\text { kemasan }\end{array}$ & $\begin{array}{l}\text { - Kemasan } \\
\text { mengembang } \\
\text { - Tekstur } \\
\text { sedikit berubah }\end{array}$ & $\begin{array}{l}\text { - Tidak ada } \\
\text { perubahan } \\
\text { dalam produk }\end{array}$ & $\begin{array}{l}\text { - Tidak ada } \\
\text { perubahan } \\
\text { dalam produk }\end{array}$ & $\begin{array}{l}\text { - Tidak ada } \\
\text { perubahan } \\
\text { dalam produk }\end{array}$ & $\begin{array}{l}\text { - Tidak ada } \\
\text { perubahan } \\
\text { dalam produk }\end{array}$ \\
\hline Kamis & $\begin{array}{l}\text { - kemasan } \\
\text { tetap } \\
\text { mengembung } \\
\text { - terdapat } \\
\text { kerusakan pada } \\
\text { produk }\end{array}$ & $\begin{array}{l}\text { •tekstur } \\
\text { mengalami } \\
\text { perubahan } \\
\text { menjadi } \\
\text { lembek }\end{array}$ & $\begin{array}{l}\text { •kemasan } \\
\text { mengembang } \\
\text { karena } \\
\text { terdapat udara } \\
\text { di dalamnya }\end{array}$ & $\begin{array}{l}\bullet \text { kemasan } \\
\text { sedikit } \\
\text { mengembang }\end{array}$ & $\begin{array}{l}\text { - Tidak ada } \\
\text { perubahan } \\
\text { dalam produk }\end{array}$ & $\begin{array}{l}\text { - Tidak ada } \\
\text { perubahan } \\
\text { dalam produk }\end{array}$ \\
\hline Jumat & $\begin{array}{l}\text { •kemasan } \\
\text { tetap } \\
\text { mengembang } \\
\text { dengan sedikit } \\
\text { cairan di } \\
\text { dalamnya }\end{array}$ & $\begin{array}{l}\text {-kemasan tetap } \\
\text { mengembung } \\
\text {-terdapat } \\
\text { cairan pada } \\
\text { produk }\end{array}$ & $\begin{array}{l}\text {-kemasan } \\
\text { mengembang } \\
\text {-tekstur mulai } \\
\text { berubah }\end{array}$ & $\begin{array}{l}\text { •kemasan } \\
\text { mengembang } \\
\text { •tekstur } \\
\text { lembek }\end{array}$ & $\begin{array}{l}\text { - Tidak ada } \\
\text { perubahan } \\
\text { dalam produk }\end{array}$ & $\begin{array}{l}\text { - Tidak ada } \\
\text { perubahan } \\
\text { dalam produk }\end{array}$ \\
\hline Sabtu & $\begin{array}{l}\text {-Terdapat } \\
\text { cairan pada } \\
\text { produk }\end{array}$ & $\begin{array}{l}\text {-kemasan tetap } \\
\text { mengembung } \\
\text {-terdapat } \\
\text { cairan pada } \\
\text { produk }\end{array}$ & $\begin{array}{l}\text { •kemasan } \\
\text { mengembang } \\
\text { •tekstur mulai } \\
\text { berubah } \\
\text { lembek }\end{array}$ & $\begin{array}{l}\text { •kemasan } \\
\text { mengembang } \\
\text { •tekstur } \\
\text { lembek }\end{array}$ & $\begin{array}{l}\text { - Tidak ada } \\
\text { perubahan } \\
\text { dalam produk }\end{array}$ & $\begin{array}{l}\text { - Tidak ada } \\
\text { perubahan } \\
\text { dalam produk }\end{array}$ \\
\hline Minggu & $\begin{array}{l}\text { - Produk sudah } \\
\text { rusak } \\
\text { - Tekstur } \\
\text { lembek }\end{array}$ & $\begin{array}{l}\text { - Produk sudah } \\
\text { rusak } \\
\text { - Tekstur } \\
\text { lembek }\end{array}$ & $\begin{array}{l}\text { - Kualitas } \\
\text { sudah tidak } \\
\text { bagus }\end{array}$ & $\begin{array}{l}\text { - Produk masih } \\
\text { berbentuk } \\
\text { - Kualitas } \\
\text { sudah tidak } \\
\text { bagus }\end{array}$ & $\begin{array}{l}\text { - Tidak ada } \\
\text { perubahan } \\
\text { dalam produk }\end{array}$ & $\begin{array}{l}\text { - Tidak ada } \\
\text { perubahan } \\
\text { dalam produk }\end{array}$ \\
\hline
\end{tabular}




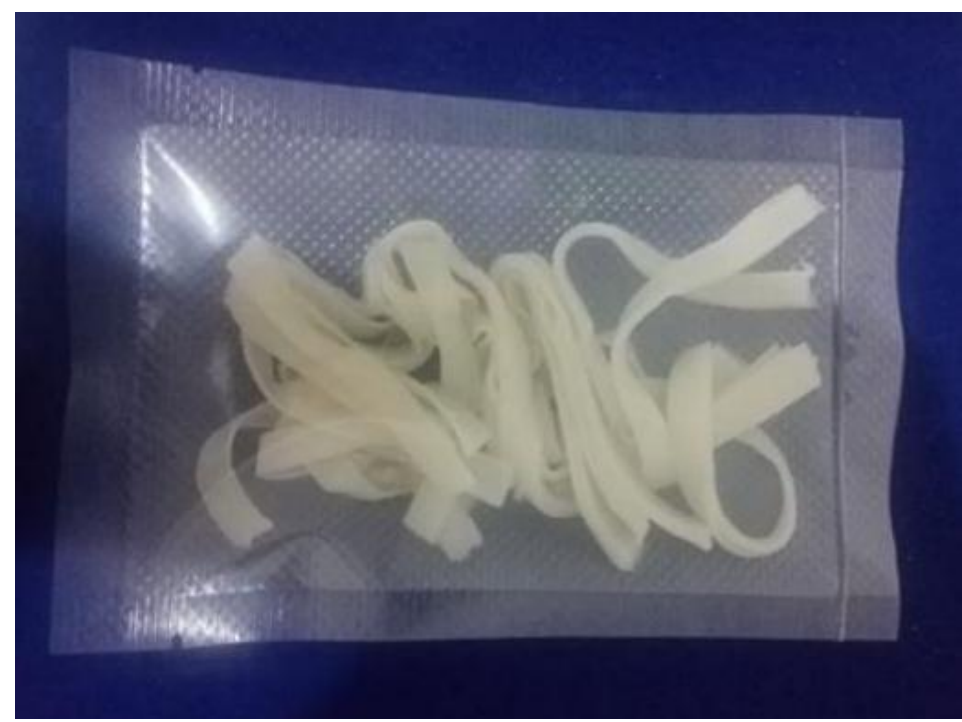

Gambar 2. Kwetiau Kacang Hijau Teri

Tekstur dari kwetiau kacang hijau teri yaitu lembut dan lunak sehingga tidak memerlukan waktu lama dalam proses mengunyah sehingga cocok dikonsumsi oleh anak-anak. Kwetiau kacang hijau teri ini memiliki aroma khas ikan teri, berwarna putih abu-abu serta berbentuk panjang dan dapat bertahan selama 2 hari pada suhu ruang, 4 hari tanpa menggunakan pengawet pada suhu kulkas, dan lebih dari seminggu pada suhu freezer.

Tabel 2. Uji Kelenturan Kwetiau

\begin{tabular}{cc}
\hline No & Kelenturan $(\mathrm{cm})$ \\
\hline Pengujuan ke 1 & 24 \\
Pengujuan ke 2 & 23 \\
Pengujuan ke 3 & 24 \\
Pengujuan ke 4 & 23.5 \\
Pengujuan ke 5 & 23.5 \\
\hline Rata-rata & 23.6 \\
\hline
\end{tabular}

Setelah di uji coba, kwetiau kacang hijau teri ini memiliki kelenturan di angka $23.6 \mathrm{~cm}$ degan melakukan 5 kali pengujian terhadap kwetiau dengan panjang produk adalah $20 \mathrm{~cm}$.

\section{Pembahasan}

Keberhasilan produk Kwetiau Kacang Hijau Teri ditentukan oleh: Pertama, proses penyaringan tepung kacang hijau dan proses penghalusan menggunakan blender kemudian di saring sampai menghasilkan bubuk halus dan menghindari terdapatnya gumpalan kasar yang dapat merusak tekstur. Kedua, tekstur yang dihasilkan tidak mudah rusak. Bentuk akhir dari kwetiau ini panjang dan lentur namun tidak mudah rusak ketika di masak dan di konsumsi. Ketiga, menghilangkan bau amis pada ikan teri dengan cara memarinasi ikan teri sebelum dikukus. Keempat, teknik sosialisasi. Sosialisasi dilakukan dengan tujuan untuk mempromosikan produk agar dikenal masyarakat, namun sosialisasi biasanya tidak dapat dilakukan seacara instan sehingga membutuhkan waktu lama sampai produk siap di terima oleh masyarakat. Kelima, teknik pendistribusian. Teknik pendistribusian dilakukan dengan 
Tabel 3. Hasil Pengujian

\begin{tabular}{ccccc}
\hline No & Parameter & Satuan & Hasil & Metode Uji/ Teknik \\
\hline 1 & Protein $(\mathrm{N} \times 6,25)$ & $\%$ & 2,70 & SNI 01-2891-1192, butir 7.1 \\
2 & Calcium (Ca) & Mg/100gram & 27,0 & A0AC 985.35 (50.1.14.2005)
\end{tabular}

tujuan supaya produk dapat dimanfaatkan sebagai produk pangan sehat yang dapat dikonsumsi oleh anak-anak serta dapat dengan mudah ditemui di pasaran.

Kwetiau berbahan substitusi tepung kacang hijau dan ikan teri memiliki manfaat sebagai makanan sehat yang kaya akan nutrisi yang baik untuk memenuhi kebutuhan nutrisi pada anak-anak. Hal ini dapat dilihat dari kandungan kacang hijau dan ikan teri yang memiliki berbagai vitamin serta mineral yang baik bagi tubuh. Produk kwetiau kacang hijau teri dapat dimanfaatkan sebagai panganan sehat yang dapat di konsumsi oleh semua usia terlebih untuk anak-anak dan dapat dijadikan sebagai produk ketahanan pangan.

\section{KESIMPULAN}

Berdasarkan penelitian ini dapat disimpulkan bahwa kwetiau kacang hijau ikan teri memiliki kandungan kalsium 27,0 $\mathrm{mg}$ dan 2,70 $\mathrm{mg}$ protein sesuai hasil pengujian yang dilakukan di Balai Besar Industri Argo (BBIA) Kota Bogor, Jawa Barat. Kwetiau kacang hijau ikan teri ini dapat dibuat dengan menggunakan teknik pengukusan serta memiliki tekstur lembut, berserat halus, dan beraroma khas kacang dan ikan serta memiliki panjang kelenturan sebesar 23,6 cm berdasarkan uji kelenturan yang dilakukan selama 5 kali percobaan. Hasil pengujian yang dilakukan terhadap kwetiau ini adalah produk dapat bertahan selama 2 hari pada suhu ruang, 4 hari pada suhu kulkas, dan lebih dari seminggu pada suhu freezer.

\section{REFERENSI}

Agriculture and Agri-food Canada. (2010). Consumers Trends Noodle In Japan. International Market of Bureau. Canada: Her Majesty the Queen in Right of Canada Aridiyah, F. O., Rohmawati, N., \& Ririanty, M. (2015). Faktor-faktor yang Mempengaruhi Kejadian Stunting pada Anak Balita di Wilayah Pedesaan dan Perkotaan (The Factors Affecting Stunting on Toddlers in Rural and Urban Areas). Pustaka Kesehatan, 3(1), 163-170.

Astawan, M. (2000). Membuat mi dan bihun. Niaga Swadaya.

BPS. (2019). Profil Kemiskinan di Indonesia Maret 2019. No 56/07/Th.XXII, 15 Juli 2019

BPS. (2019). Impor Biji Gandum dan Meslin Menurut Negara Asal Utama, 2010-2018. Retrieved from https://www.bps.go.id/statictable/2019/02/14/2016/impor-bijigandum-dan-meslin-menurut-negara-asal-utama-2010-2017.html

Dharmayanti, A. W. S. (2014). Manfaat ikan teri segar (Stolephorus sp) terhadap pertumbuhan tulang dan gigi. ODONTO: Dental Journal, 1(2), 52-56. 
Gunawan, H. A. (2008). RETENSI DAN INTRUNSI FLUOR PADA PERMUKAAN EMAIL SETELAH APLIKASI DENGAN SUBSTRAT IKAN TERI (Stolephorus sp.). Journal of Dentistry Indonesia, 10(3), 793-797.

Koswara, S. (2009). Teknologi pengolahan mie. Seri Teknologi Pangan.

Kuntari, T., Jamil, N. A., \& Kurniati, O. (2013). Faktor risiko malnutrisi pada balita. Kesmas: National Public Health Journal, 7(12), 572-576.

Kusnandar, (2019). Konsumsi Mi Instan Indonesia 2018 Turun 0,63 Persen. Retrieved from https://databoks.katadata.co.id/datapublish/2019/07/03/konsumsi-mi-instan-indonesia$\underline{\text { turun }}$

Lambrides, C. J., \& Godwin, I. D. (2007). Mungbean. In Pulses, sugar and tuber crops (pp. 69-90). Springer, Berlin, Heidelberg.

Ladamay, N. A., \& Yuwono, S. S. (2013). Pemanfaatan Bahan Lokal Dalam Pembuatan Foodbars (Kajian Rasio Tapioka: Tepung Kacang Hijau Dan Propo Rsi Cmc)[In Press Januari 2014]. Jurnal Pangan dan Agroindustri, 2(1), 67-78.

Lawang, A. T. (2013). Pembuatan Dispersi Konsentrat Ikan Gabus (Ophiocephalus Purwono, dan R. Hartono. 2005. Kacang Hijau. Penebar Swadaya. Jakarta.Striatus) Sebagai Makanan Tambahan (Food Supplement) (Doctoral dissertation).

Prasetya, F. B. (2020). Makan Ikan Teri Selama Menyusui Dapat Mencegah Ibu Terkena Osteoporosis. Retrieved from https://hellosehat.com/parenting/bayi/manfaat-ikan-teriibu-menyusui/\#gref

Purnasari, S. D. (2015). Pengaruh Substitusi Tepung Ikan Teri tehadap Mutu Organoleptik dan Kadar Kalsium Kwetiau. 